\title{
ANALYSIS OF POWER SUPPORT BEHIND PILE AND GIRDER BRIDGE ABUTMENT RANDUMERAK LOAD ON VERTICAL AND HORIZONTAL (CASE STUDY VILLAGE RANDUMERAK DISTRICT, DISTRICT PAITON, PROBOLINGGO)
}

\author{
Dimas Wahyu Tri Pamungkas \\ Faculty Of Engineering \\ Narotama University, Surabaya \\ wdimas749@gmail.com \\ Helmy Darjanto \\ Faculty Of Engineering \\ Narotama University, Surabaya
}

\begin{abstract}
Construction of pile foundations is also called a foundation in construction enabled to heavy loads (high rise building). Before the implementation of the construction of the first construction is implemented and carried out in the field is the work of the foundation (bottom structure). Foundation work itself is very important for civil engineering works, because this is the foundation that secures simultaneously carry the load working on the construction. This study aimed to analyze the carrying capacity and the forces acting on the pile working from the Standard Penetration Test (SPT), the data kalendering pile installation time, then the data terbebut in include into the application to determine how far the resilience of construction are already working. Methodology The data collection is done by making observations, collecting data from the project and conduct a literature study. From the analysis of the structure obtained by the forces at work in the use of the calculation of the structure. The calculations show that the pile cap and slab reinforcement in accordance with the moment that occurs, the strength and bearing capacity of the pile meet safety requirements.
\end{abstract}

Keywords : Foundations, piles, bridges, abutments

\section{INTRODUCTION}

The bridge is a structure that crosses the river, bay, or other conditions such hurdles are lower, thereby enabling rail vehicles and pedestrians passed smoothly and safely. The bridge is the highest investment of all the elements that can be found on the highway system.

Bridges as transport infrastructure has a dominant advantage for the movement of traffic. The bridge is a common isitilah for construction that was built as a transportation hub that crosses rivers, lakes, swamps, ravines and other obstacles. The importance of the bridge in the life bermasyrakat and nation that can improve the defense, welfare and security of a nation, when things happen that are not desirable and could destabilize the region and nationally.

Based on the description above, it can be concluded that the bridge has a very important role in the activity of a society, nation and state in various fields, so the need for special attention in the construction and maintenance. As in the bridge construction Randu 
Peacock Paiton Probolinggo District of connecting the village of Desa Randu Peacock Kraksaan and that serves as a liaison between the two regions.

Based on the above, the problem can be formulated as follows:

Is the foundation bearing piles already meet a given load?

How big pile bearing capacity of the soil groups with varying amounts of sand argillaceous pole test method of modeling?

In order to minimize the occurrence of the problem in this research study, the need for restrictions. boundary issues can be seen as follows:

1. Only reviewed perpendicular to the stake.

2. The calculation of the carrying capacity of the pile under the terms PT. WIKA concrete and SPT test.

3. Only reviewed axial bearing capacity for pile group.

4. This thesis is focused on how the mechanism of burden borne by the bottom of the bridge structure.

In the manufacture and the results of this study conducted with the intent and purpose as follows:

1. Calculating the load carrying capacity of the pile against a given load.

2. Calculate the pile bearing capacity of the soil groups with varying amounts of sand argillaceous pole test method of modeling software.

\section{Literature review}

In this chapter will discuss the foundation pile which is commonly used in the construction of bridge foundations. Especially to be described here is for the foundation piles are absolutely necessary basic data about the soil and carrying Single Pile and Pile Group.

For it is necessary to obtain data Boring testing ground. As well as the required bearing capacity calculation based on the method Calendering / erection and loading test.

In general, slab foundations have provisions as follows:

Able to pass the vertical forces exerted on it to be forwarded kelapisan ground support (bearing layers).

With the relationship between the heads of the pole of one another are able to withstand changes in certain forms of horizontal direction (perpendicular to the axle pole).

\section{definition Land}

In the Land consists of three components, namely air, water and solid materials. Air technically considered to have no effect, while greatly affects water engineering properties of soil. The space between the grains, can be partially or completely filled by water or air. When the cavity is completely filled with water, the soil is said to be in a saturated condition. When the cavity is filled with air and water, soil on kondisijenuh partially (partially saturated). Dry soil is soil that contains no water at all or the water level is zero.

Land, on natural conditions, consisting of a mixture of mineral granules with or without organic matter content. The granules can be easily separated from one another with water suitability. This material comes from the weathering of rocks, both physically and chemically. Engineering properties of soil, except by the nature of the host rock which is the origin of the material, also is affected by outside elements that are becoming peyenbab occurrence of the rock weathering.

Terms such as gravel, sand, silt and clay used in civil engineering jens distinguishing soils. In natural conditions, soil may consist of a mixture of two or more types of soil and sometimes there is also an organic matter content. Material mixture is then used as an additional name behind the main element material. For example, berlanau clay is clay that contains the main material is clay and sebgainya. 


\section{Field investigations With the Standard Penetration Test (SPT)}

SPT method is a method of fixing the rod (which has a tip erection) into the ground using a hammer blow and blow perkedalaman measure the amount of penetration. This method has been standardized as ASTMD 1586 since 1958 with periodic revisions until now. Piling is usually done with a load of $140 \mathrm{lbs}(635 \mathrm{~kg})$ dropped from a height of 30 "or \pm 75 $\mathrm{cm}$.

Observation and calculation is performed as follows:

a. SPT tube initially beaten into the ground as deep as $45 \mathrm{~cm}$ is the depth expected to be disturbed by drilling.

b. Then for each depth of $15 \mathrm{~cm}$ recorded the number of strokes needed to enter it. The number of blows to post a split spoon $15 \mathrm{~cm}$ first recorded as $\mathrm{N} 1$. The number of blows to post a $15 \mathrm{~cm}$ second is N2 and the number of strokes to enter the third is $15 \mathrm{~cm} \mathrm{N3}$. so the total depth after testing SPT is $45 \mathrm{~cm}$ and produces N1, N2 and N3.

c. Figures 2 SPT determined by summing the number last blow (N2 + N3) at each testing interval and recorded on the sheet Drilling Log.

d. Upon completion of the test, SPT tube removed from the borehole to the surface land for soil samples were taken and put into a plastic bag to be observed in the laboratory.

The results of the work Bor and SPT then poured in the drilling log sheet that contains:

- Description of land includes soil type, soil color, degree of plasticity and thickness of the layer of soil each - each.

- Native soil sampling / undisturbed sample (UDS).

- Testing Standard Penetration Test (SPT).

- Ground water level.

- Expiration date of employment and occupation.

Total $\mathrm{N}$ punches provide guidance on the relative density of the soil, especially in the field of gravel and sand or soil type barrier against penetration. This test is usually used to the hard ground.

\section{Capability Analysis of Lateral On Piles}

Vertical style pedestal resist lateral loads to mobilize passive pressure on the surrounding soil. The level distribution of ground reaction depends on the stiffness of the pole, the rigidity of land, and the accuracy of the pile. On the pedestal were loaded laterally general can be divided into two main categories, namely short or stiff in the pedestal and the pedestal length or elastic. The image below shows some variation characteristic of the nature and distribution mast deflection moments and shear forces along the long pole when the stack undergo lateral loading.

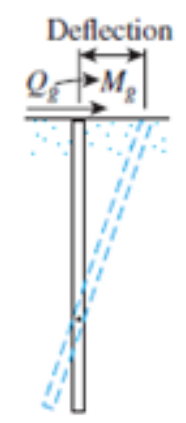

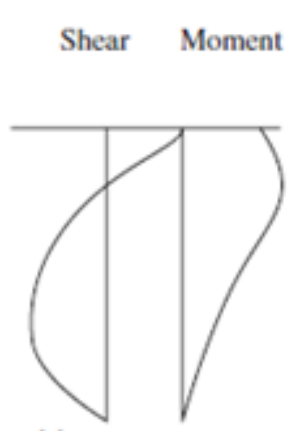

(a)

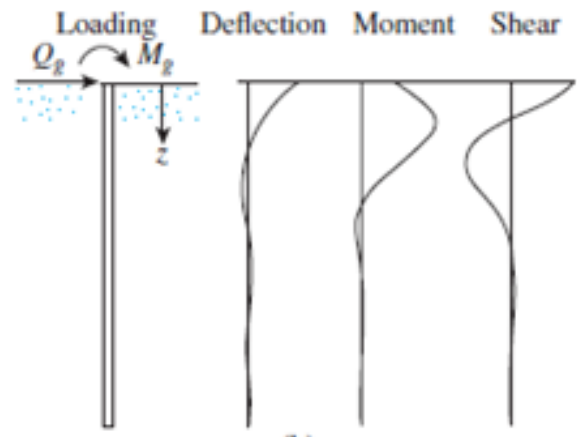

(b)

Picture 1 Rigid pedestal (a) and the elastic pedestal (b) (Braja M. Das, 2016)

\section{Elasticity solution}

The general method to determine the moment and the displacement of the vertical poles 
embedded in granular soils and experience lateral loads and moments on the surface soil by Matlock and Reese (1960). Consideration pedestal length $L$ is subjected to a lateral force and moment on the soil surface $\left(z_{2}=0\right)$, as shown in the figure below which shows the pole deflected shape in general and soil resistance caused by the layer contained in the moment. $Q_{g} M_{g}$

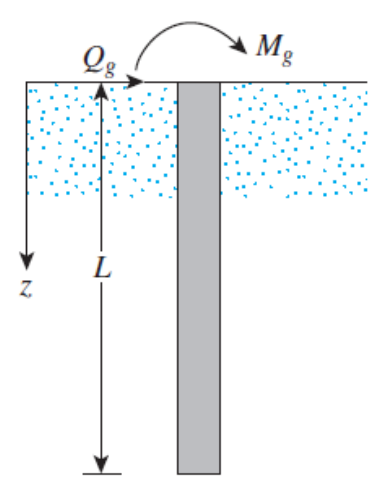

(a)

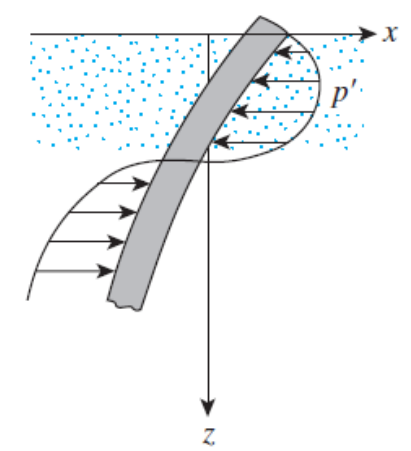

(b)
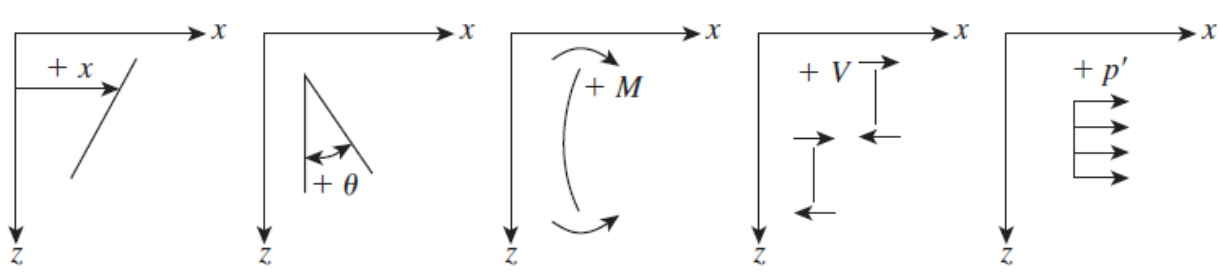

(c)

Figure 2 (A) The pile loaded laterally, (b) resistance of the soil on the mast caused by the lateral load, (c) sign a convention for displacement, tilt, moment, shear, and ground reaction (Braja M. Das, 2016).

$k=\frac{p^{\prime}(k N / \text { matau } l b / f t}{x(\text { matau } f t)}$

Where:

$K=$ Modulus of soil reaction

$P^{\prime}=$ Pressure Land

$x=$ deflection

Modulus of subgrade of granular soil at a depth $\mathrm{z}$ is defined as follows: $k_{\mathrm{z}}=n_{\mathrm{h}} \mathrm{z}$

Where $=$ constant modulus reaaksi horizontal subgrade. Referring to Figure 2.1 and uses the theory of beams on elastic foundation, we can write denngan $n_{\mathrm{h}}$

$$
\text { (2.2) } E_{\mathrm{P}} I_{\mathrm{P}}=\frac{d^{4} x}{d \mathrm{z}^{4}}=p^{\prime}
$$

Where:

$E_{\mathrm{P}}=$ Modulus of elasticity of the material pile

$I_{\mathrm{P}}=$ Moment of inertia on the part of the pole.

Based on the model Winkler

$P^{\prime}=-k x$

Sign negative equation for the ground reaction in the opposite direction of the deflection of the pile. Combining Equations and gave the following values. 
$E_{\mathrm{P}} I_{\mathrm{P}}=\frac{d^{4} x}{d \mathrm{z}^{4}}+k x=0$

\section{Distribution Expenses In Column Group}

Load Analysis in particular pedestal in a pile group can be calculated using the elastic equation:

$Q_{\mathrm{m}}=\frac{Q}{n} \pm \frac{M_{\mathrm{y}} x}{\sum\left(x^{2}\right)} \pm \frac{M_{\mathrm{y}} y}{\sum\left(y^{2}\right)}$

Where:

$Q_{\mathrm{m}}=$ The axial load on each pole $\mathrm{m}$.

$Q=$ total vertical load acting on the center of mass of pile groups.

$n=$ The number of poles.

$M_{\mathrm{x}} M_{\mathrm{y}}=$ Relationships each moment with $\mathrm{x}$ and $\mathrm{y}$ axis.

$x, y=$ The distance of each pole to the $y$-axis and $x$.

(Both $x$ and $y$ axis through the center of mass of the cluster pole and perpendicular to each other.) It should be noted that the cuts and the bending moment can be determined for each piece pile cap using the elastic equation and static.

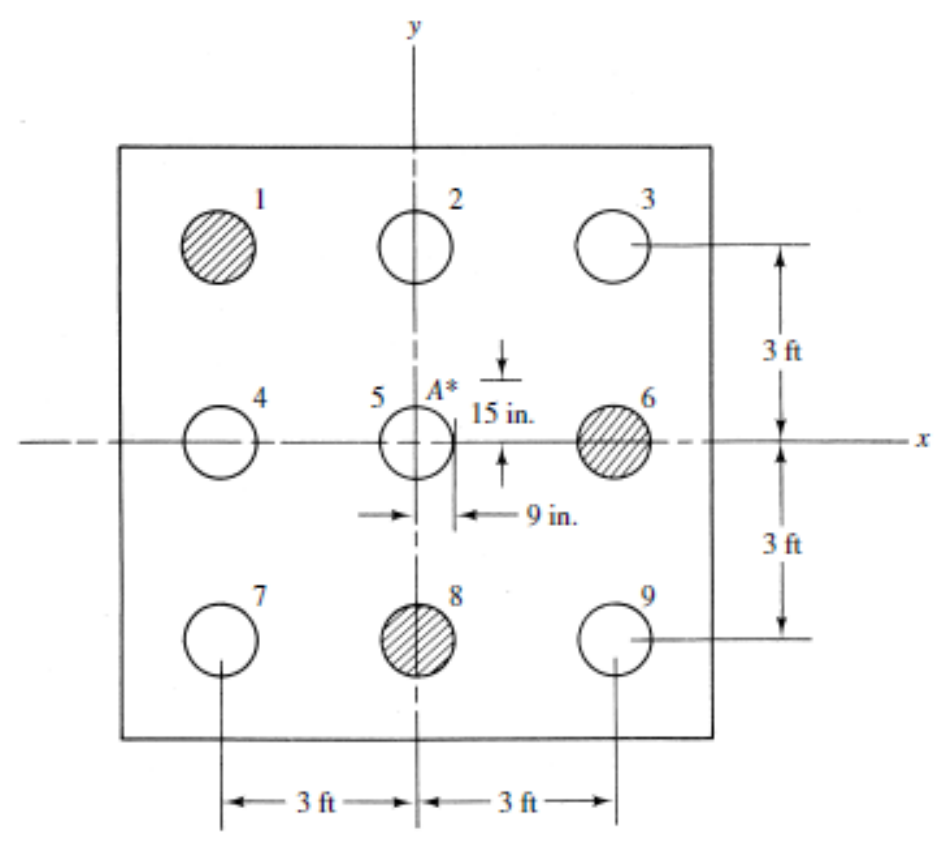

Figure 3 Sample loading pole group (Soils AND

FOUNDATIONS 2008) 


\section{Efficiency Column Group}

Mobilization piling pressure on the arrangement depicted schematically in Figure 4.

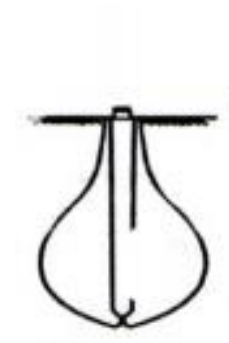

(a)

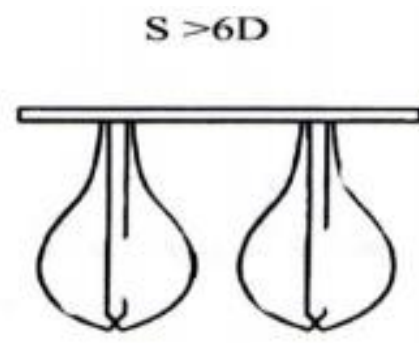

(b)
$2 \mathrm{D}<\mathrm{S} \leq 6 \mathrm{C}$

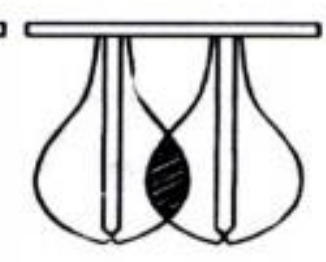

(c)

Sumber: Pradoto (1998) dalam Rini (2014)

Figure 4 Schematic mobilization of pressure (Pradoto, 1998)

Based on the schematic, Pradoto (1998) in Rini (2014) provides an explanation:

The shape of the voltage diagram in the form of bubbles collapse at one pole.

Bubble pressure on the set of the pole where the pole spacing $S>6 D$ (pole calculation group); with $\mathrm{D}=$ diameter.

Bubble pressure on the pole where the pole spacing group 2,5D $<S<6 \mathrm{D}$ (pole calculation group); with $\mathrm{D}=$ diameter.

The bearing capacity of pile group permission is obtained by multiplying the power Ukung permits axial with the pole group efficiency. The equation for calculating the efficiency of pile groups using equation Converse-Labarre formula in Hardiyatmo (2014) as follows.

$$
\mathrm{Eg}=1-\theta
$$$$
\text { (2.10) } \frac{(n-m) \cdot m+(m-1) n}{90 . n \cdot m}
$$

Where:

$$
\begin{array}{ll}
\text { eg } & =\text { Efficiency pole group; } \\
\Theta & =\text { Arc tan D / S in degrees }\left({ }^{\circ}\right) \\
n & =\text { Number of poles in a row (fruit) } \\
\mathrm{m} & =\text { Number of lines in the pole (fruit) } \\
\mathrm{D} & =\text { Diameter of the pole }(\mathrm{m}) \\
\mathrm{S} & =\text { Distance between poles }(\mathrm{m})
\end{array}
$$

\section{Design Analysis Using Software Foundation ALLPILE V6.5e}

Designing Foundations provide challenges for the Civil Engineer. Given the importance of the foundation elements of the reliability of the overall construction. Plus so many factors that can not be measured with certainty is generally associated with the land. To simplify the calculations, the software used in this study as the basis for calculation ALLPILE V6.5e. 


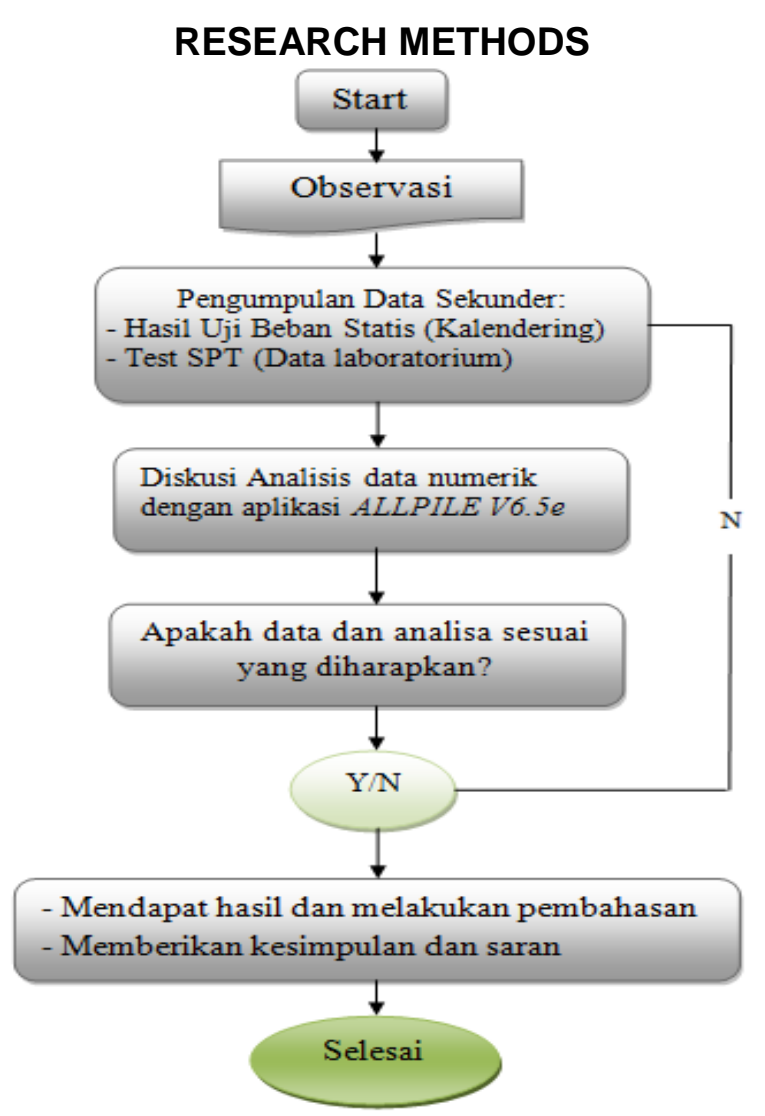

Picture 4 flowchart Analysis

\section{RESULTS AND DISCUSSION}

On the bridge carrying capacity analysis in this study required SPT data obtained from the contractor who examined the soil data at certain depths.

table 1 Recap SPT test results (PU Highways, 2018)

\begin{tabular}{|c|c|c|c|}
\hline \multicolumn{1}{|c|}{ Depth } & \multicolumn{1}{|c|}{ Type of soil } & Color & $\begin{array}{c}\text { SPT value } \\
\text { Depth }(\mathrm{m})\end{array}$ \\
\hline 0 to 2.5 & Clay & Chocolate & 3 \\
\hline 2.5 to 4.5 & clay Kepasiran & Chocolate & 5 \\
\hline $4.5-6.5$ & sand Kelempungan & Brown Gray & 9 \\
\hline 6.5 to 8.5 & sand Kelempungan & Gray & 15 \\
\hline 8.5 to 12.5 & $\begin{array}{c}\text { Fine sand } \\
\text { Kelempungan }\end{array}$ & Little black and white & 6 \\
\hline 12.5 to 16.5 & Fine sand & Black & 5 \\
\hline
\end{tabular}




\begin{tabular}{|c|c|c|c|}
\hline & Kelempungan & & 11 \\
\hline 16.5 to 18.5 & sand Kelempungan & Black & 33 \\
\hline 18.5 to 20.5 & $\begin{array}{c}\text { Solid sand } \\
\text { Kelempungan }\end{array}$ & Black & 40 \\
\hline 20.5 to 24.5 & The S & Chocolate & 50 \\
\hline 24.5 to 30 & Solid clay & Chocolate & \\
\hline
\end{tabular}

\section{Structure Data Analysis Bridge}

Data structure of the bridge is data related to construction in general. The data structure of the bridges on the road section Randu Merak as follows.

Table 2 Structure of Upper Bridge (PU Highways, 2018)

\begin{tabular}{|l|c|c|c|}
\hline DESCRIPTION DIMENSIONS & Notation & BIG & UNIT \\
\hline The width of the road (traffic lane) & $\mathrm{b}^{1}$ & 7 & $\mathrm{~m}$ \\
\hline $\begin{array}{l}\text { The width of the sidewalk } \\
\text { (pedestrian) }\end{array}$ & $\mathrm{b}^{2}$ & 1.50 & $\mathrm{~m}$ \\
\hline $\begin{array}{l}\text { The width of the median (dividing } \\
\text { lines) }\end{array}$ & $\mathrm{b}^{3}$ & 1.50 & $\mathrm{~m}$ \\
\hline The total width of the bridge & $\mathrm{b}$ & 8.50 & $\mathrm{~m}$ \\
\hline Thick floor slab bridge & $\mathrm{t}_{\mathrm{s}}$ & 0.20 & $\mathrm{~m}$ \\
\hline Thick layers of asphalt + overlay & $\mathrm{t}_{\mathrm{a}}$ & 0.10 & $\mathrm{~m}$ \\
\hline thick pavement & $\mathrm{t}_{\mathrm{t}}$ & 0.30 & $\mathrm{~m}$ \\
\hline Thick rain puddles & $\mathrm{t}_{\mathrm{h}}$ & 0.05 & $\mathrm{~m}$ \\
\hline High prestressed girder & $\mathrm{h}_{\mathrm{b}}$ & 2.10 & $\mathrm{~m}$ \\
\hline High field beside the bridge & $\mathrm{h}_{\mathrm{a}}$ & 2.75 & $\mathrm{~m}$ \\
\hline $\begin{array}{l}\text { The distance between the beams } \\
\text { prestressed }\end{array}$ & $\mathrm{S}$ & 1.40 & $\mathrm{~m}$ \\
\hline Long-span bridges & $\mathrm{L}$ & 40 & $\mathrm{~m}$ \\
\hline \multicolumn{1}{|c|}{ SPECIFIC GRAVITY } & Notation & $\mathrm{BIG}$ & $\mathrm{UNIT}$ \\
\hline Heavy concrete & $\mathrm{w}_{\mathrm{c}}=$ & 25 & $\mathrm{kN} / \mathrm{m}^{3}$ \\
\hline $\begin{array}{l}\text { Heavy reinforced concrete } \\
\text { (concrete rebate) }\end{array}$ & $\mathrm{w}^{\prime}{ }_{\mathrm{c}}=$ & 24 & $\mathrm{kN} / \mathrm{m}^{3}$ \\
\hline heavy bitumen & $\mathrm{w}_{\mathrm{a}}=$ & 22 & $\mathrm{kN} / \mathrm{m}^{3}$ \\
\hline Density of water & $\mathrm{w}_{\mathrm{w}}=$ & 9.8 & $\mathrm{kN} / \mathrm{m}^{3}$ \\
\hline
\end{tabular}

\section{Calculation of Upper Structure}

The bridge structure above is very simple because it consists of a slab and pile cap that rested directly to the pile foundation. Piece lengthwise and crosswise bridgegirder Peacock Randu road can be seen in the following figure.

a) Technical data on the structure of the bridge structure

Total long-bridge,

Long Segment,
$\mathrm{Lt}=40.8 \mathrm{~m}$

$$
\mathrm{L}=5 \mathrm{~m}
$$


The total width of the Bridge,

The width of the traffic lanes,

Parabet wall width,

$\mathrm{B}=8.5 \mathrm{~m}$

$\mathrm{tb}=0.4 \mathrm{~m}$

Thick layers of asphalt,

Thick rain puddles,

$\mathrm{b}=7 \mathrm{~m}$

The total length of the pile, $\quad \mathrm{Lpt}=24 \mathrm{~m}$

The long pole in the ground, $L p=22 \mathrm{~m}$

Diameter piles,

$\varnothing=0.6 \mathrm{~m}$

Transverse distance between poles $\mathrm{s}=1.5 \mathrm{~m}$

Distance pole to the outer side of the bridge $\mathrm{a}=1.0 \mathrm{~m}$

\section{Identification of Soil Conditions On The Ground}

The soil conditions in the field greatly affect the stability of the structure. Testing is required at some point to determine the characteristics of the soil at the job site. Party planners have tested the soil by means of SPT (Standard Penetration Test) at 4 different points are shown in the following figure.

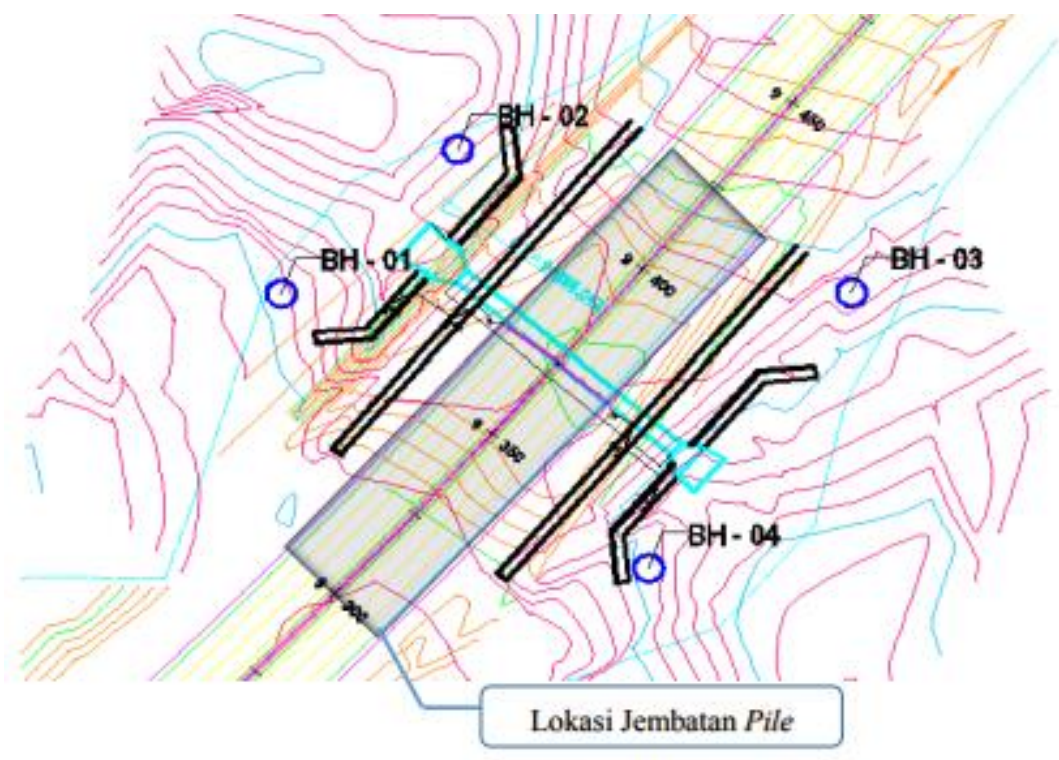

Figure 5. Topographic map SPT test point

Seen from the figure that the N-SPT testing performed at 4 different points as the orientation of the side and end of the bridge. For the calculation of the carrying capacity of the stake in V6.5e ALLPILE applications must use the value of the average of the four test points. This is intended to represent equally the soil so close to its original state in the field. N-SPT value of the average presented in Table 3. 
Table 3. N-SPT value average (PU Highways, 2018)

\begin{tabular}{|c|c|c|c|c|}
\hline \multicolumn{2}{|c|}{$\begin{array}{c}\text { Kedalaman } \\
\text { (m) }\end{array}$} & \multirow{2}{*}{$\begin{array}{c}\text { Perbedaan } \\
\text { Kedalaman, } \Delta \\
\text { (m) }\end{array}$} & \multirow[t]{2}{*}{ N-SPT } & \multirow{2}{*}{$\begin{array}{c}\Delta \times \text { N-SPT } \\
\text { (ton } / \mathrm{m} \text { ) }\end{array}$} \\
\hline $\mathrm{Z1}$ & Z1 & & & \\
\hline 8 & 10 & 2 & 9,25 & 18,5 \\
\hline 10 & 12 & 2 & 19,00 & 38 \\
\hline 12 & 14 & 2 & 21,75 & 43,5 \\
\hline 14 & 16 & 2 & 22,50 & 45 \\
\hline 16 & 18 & 2 & 35,25 & 70,5 \\
\hline 18 & 20 & 2 & 36,75 & 73,5 \\
\hline 20 & 22 & 2 & 40,25 & 80,5 \\
\hline 22 & 24 & 2 & 45,50 & 91 \\
\hline 24 & 26 & 2 & 45,00 & 99,5 \\
\hline 26 & 28 & 2 & 49,75 & 99,5 \\
\hline 28 & 30 & 2 & 55,00 & 110 \\
\hline \multicolumn{4}{|c|}{ Sumber: Hasil perhitungan } & 792,5 \\
\hline
\end{tabular}

\section{Calculation Software Capability With ALLPILE V6.5e}

In the calculation of ALLPILE disoftware V6.5e, pile foundation structure modeled into the image piece by using the data / value derived from the field and laboratory are available, as well as the loading of data available. follows.

Steps count pile foundation structure modeling in ALLPILE V6.5 application is as

Choosing the type of material and dimensions used. In this case the type used is the type of precast pile matric calculation.

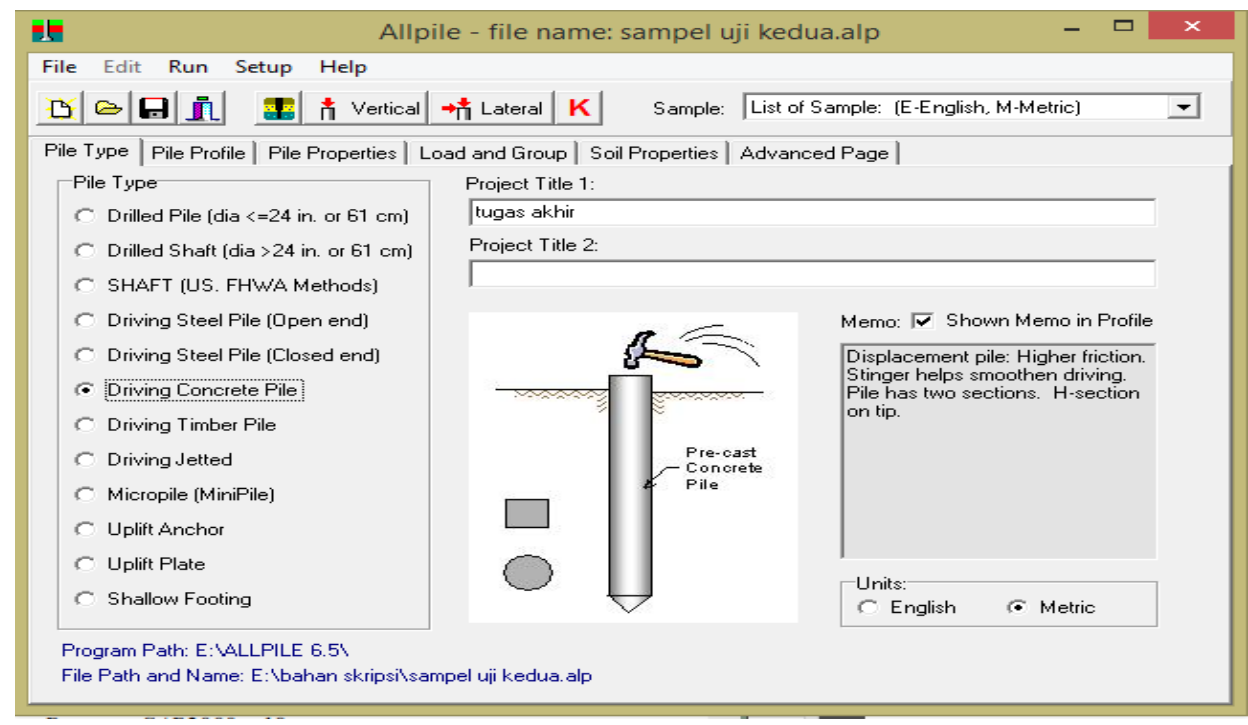

Figure 6 Types of materials and types of calculations 
Click on the toolbar Pile Profile to determine the size of the material to be analyzed.

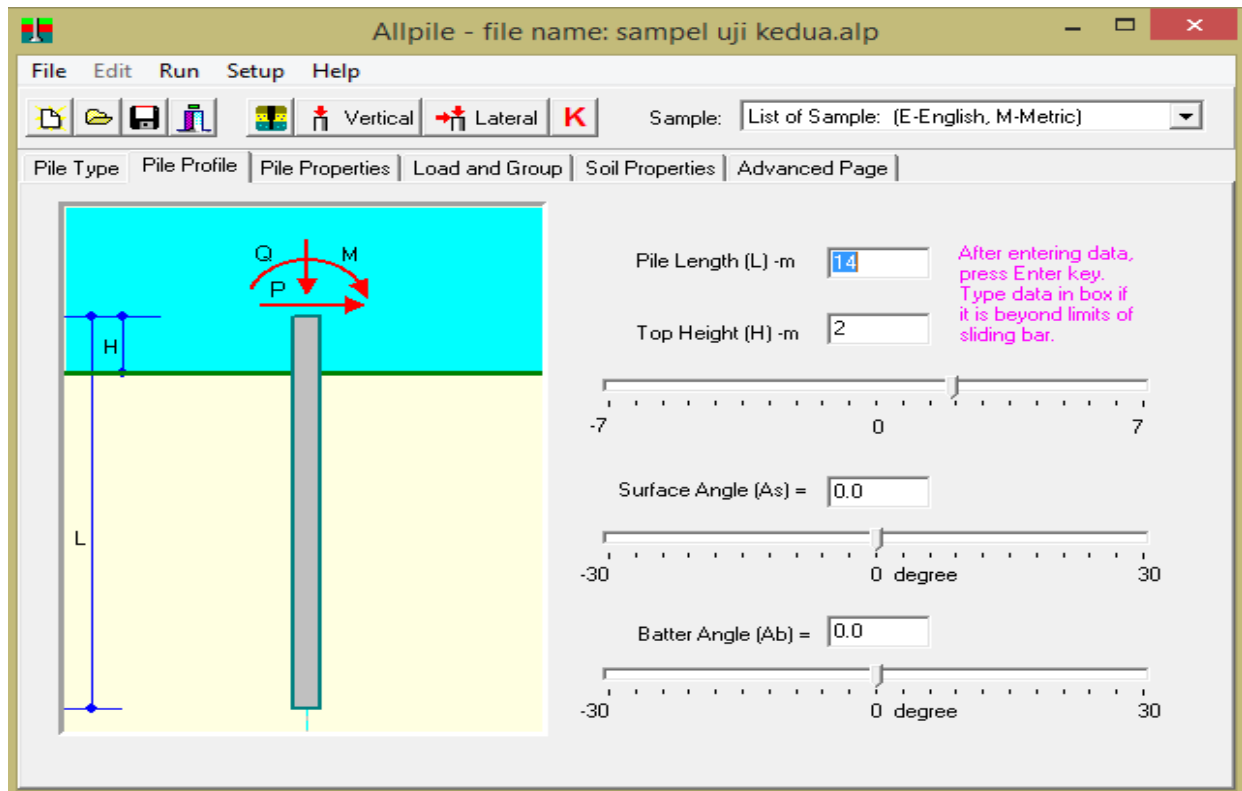

Figure 7 Determine the dimensions and the angle of the pole.

Click on the toolbar Pile Properties to determine properties in accordance with the planning structure.

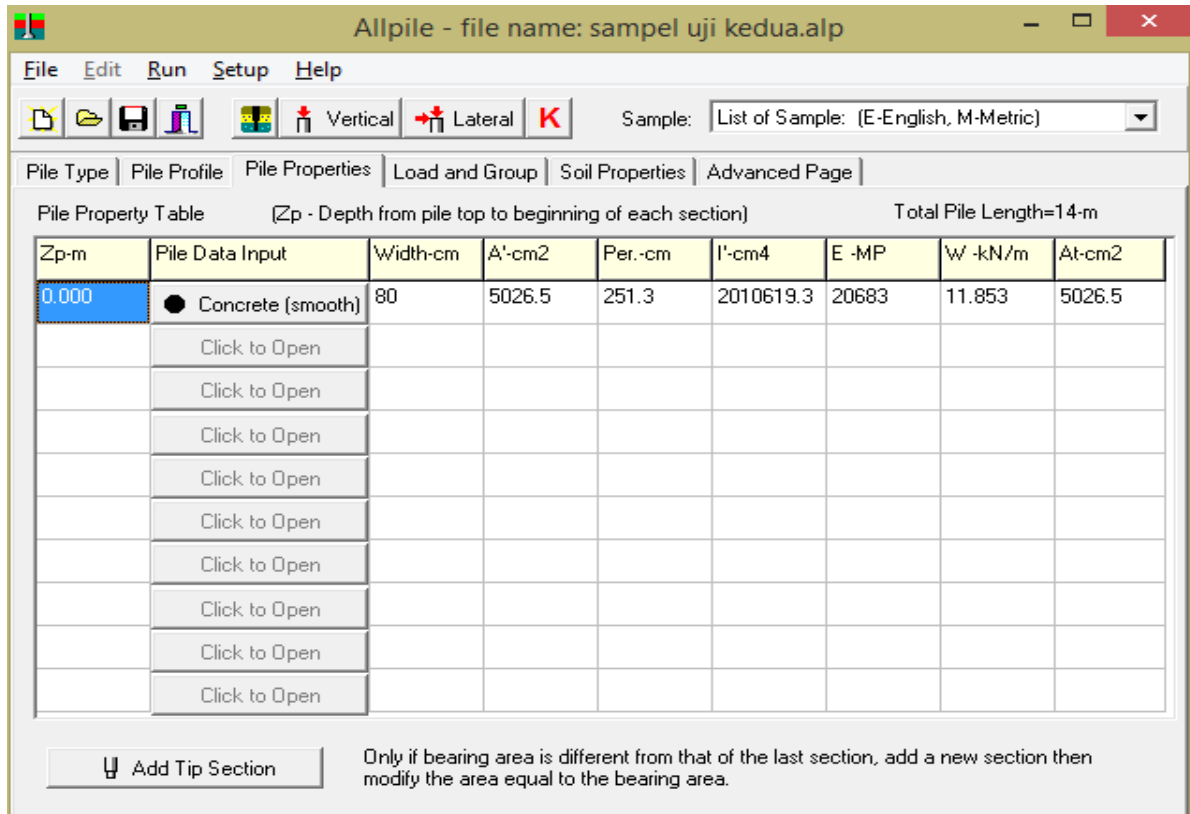

Figure 8 Selection of the type of property used. 
Then click on the toolbar load and group, to determine the pole and the calculation of a single group, as well as the loading of data input will be analyzed.

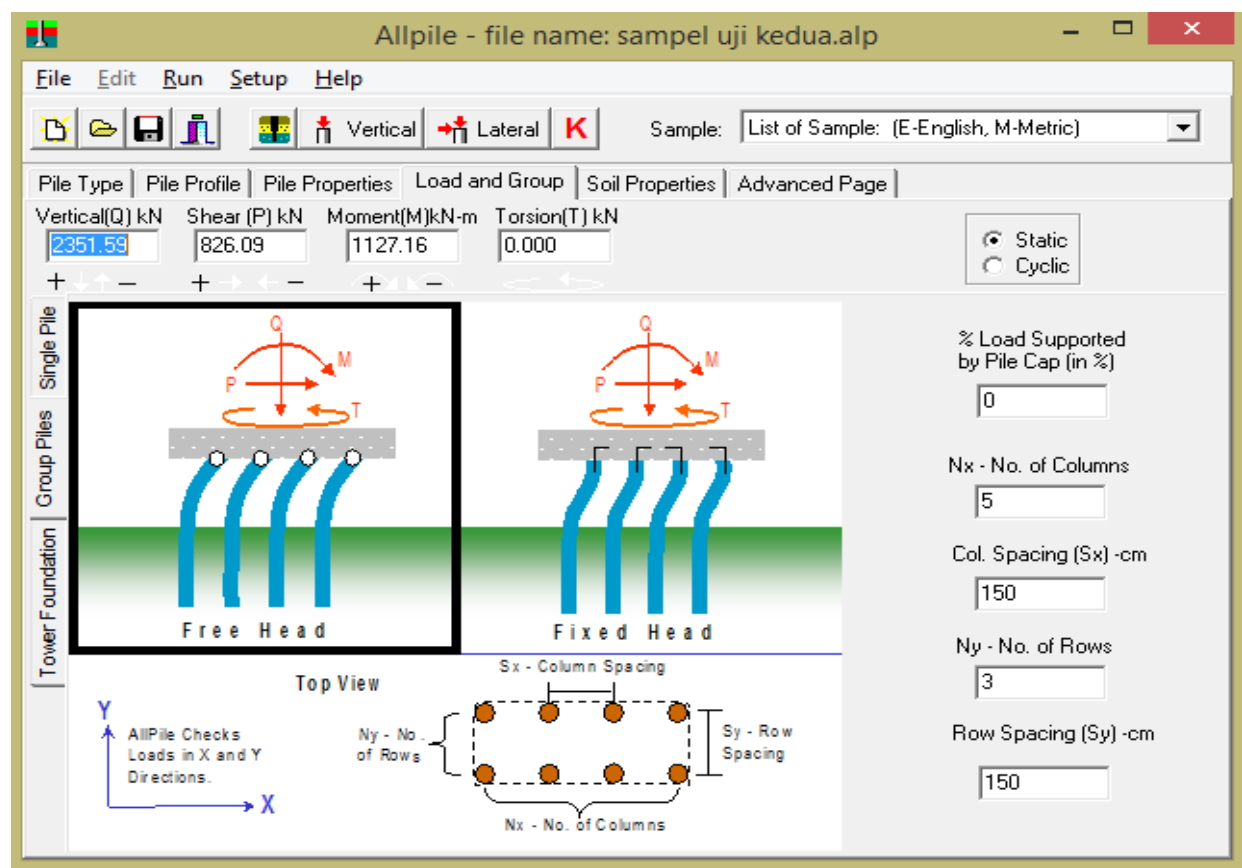

Figure 9 Selection of the type of calculation used.

Then click on the toolbar Soil properties, namely to determine what type of soil at a depth of material to support the load above.

\begin{tabular}{|c|c|c|c|c|c|c|c|c|c|}
\hline 上 & \multicolumn{6}{|c|}{ Allpile - file name: sampel uji kedua.alp } & - & $\square$ & \multirow[t]{2}{*}{$\times$} \\
\hline \multicolumn{9}{|c|}{ File É dit Run Setup Help } & \\
\hline $0|\otimes| ⿴ 囗 十)$ & 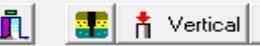 & $\Rightarrow$ 光 Lateral & & ample: Lis & of Sample: 1 & E-English, M- & Metric] & & 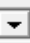 \\
\hline \multicolumn{10}{|c|}{ Pile Type | Pile Profile | Pile Properties | Load and Group Soil Properties |Advanced Page | } \\
\hline \multicolumn{2}{|c|}{$\begin{array}{l}\text { Soil Property Table }[\mathrm{Zg} \text {-Distance from } \\
\text { ground to beginning of each layer] }\end{array}$} & \multicolumn{4}{|c|}{$\begin{array}{l}\text { Water Table (An additional layer } 2.5 \\
\text { is required at water table) }\end{array}$} & \multicolumn{2}{|c|}{$\begin{array}{l}\text { Surface Elevation } \\
\text { [0ptional input] }\end{array}$} & & \\
\hline Zg-m & Soil Data Input & $\mathrm{G}-\mathrm{kN} / \mathrm{m} 3$ & Phi & $\mathrm{C}-\mathrm{kN} / \mathrm{m} 2$ & $\mathrm{k}-\mathrm{MN} / \mathrm{m} 3$ & e50 or $\mathrm{Dr}$ & Nspt & Type & \\
\hline 0.000 & $\bar{\equiv} \overline{\bar{z}}$ Soft Clay & 15.0 & 0.0 & 18.0 & 11.3 & 1.81 & 3 & 1 & \\
\hline 2.5 & $\bar{\equiv} \equiv$ Soft Clay $[\mathrm{W}]$ & 15.0 & 0.0 & 18.0 & 11.3 & 1.81 & 3 & 1 & \\
\hline 2.5 & $\overline{=}=\overline{\text { Soft Clay [W] }}$ & 15.3 & 0.0 & 23.3 & 14.6 & 1.55 & 4 & 1 & \\
\hline 8.5 & $\therefore$ Sand/Gravel[W] & 7.7 & 31.6 & 0.0 & 6.2 & 27.94 & 8 & 4 & \\
\hline 8.5 & $\therefore$ Sand/Gravel[W] & 7.1 & 30.0 & 0.0 & 3.9 & 20.65 & 5 & 4 & \\
\hline 16.5 & $\because$ Sand/Gravel[W] & 6.9 & 29.5 & 0.0 & 3.4 & 18.58 & 5 & 4 & \\
\hline 16.5 & $\because$ Sand/Gravel[W] & 8.8 & 34.7 & 0.0 & 12.8 & 43.80 & 14 & 4 & \\
\hline 20.5 & $\therefore$ Sand/Gravel[w] & 8.8 & 34.7 & 0.0 & 12.6 & 43.39 & 14 & 4 & \\
\hline 20.5 & $\therefore$ Sand/Gravel[W] & 9.9 & 38.9 & 0.0 & 33.1 & 75.13 & 40 & 4 & \\
\hline 30 & $\therefore$ Sand/Gravel[W] & 9.9 & 38.9 & 0.0 & 33.1 & 75.13 & 40 & 4 & \\
\hline
\end{tabular}

Figure 10 Determination of soil types and grades N-SPT

1. Once all the data terinput correctly and in accordance with a plan, to mengetahaui calculation analysis results desired, and then click the appropriate toolbar vertical and lateral kebutuan result.

2. Make sure that all the data required in the application terinput correctly, then the application will display the desired calculation results window.

3. The results of numerical modeling can be seen in the picture below. 


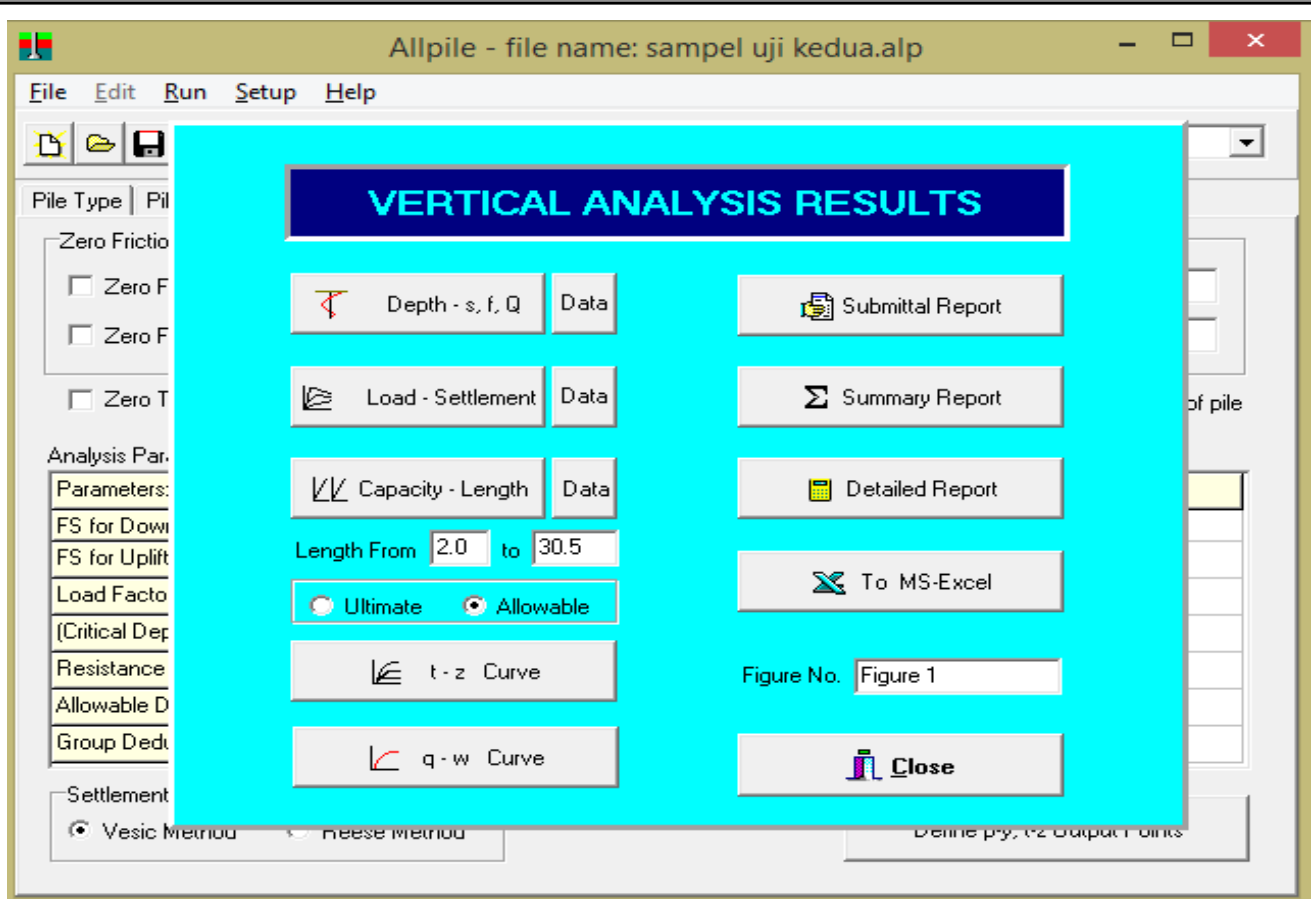

Figure 11 Window on the calculation

Vertical Load Calculation Results From Application ALLPILE V6.5e

Graph the results of calculation of soil depth (Depth).

SOIL STRESS, SIDE RE SISTANCE, \& AXIAL FORCE vS DEPTH

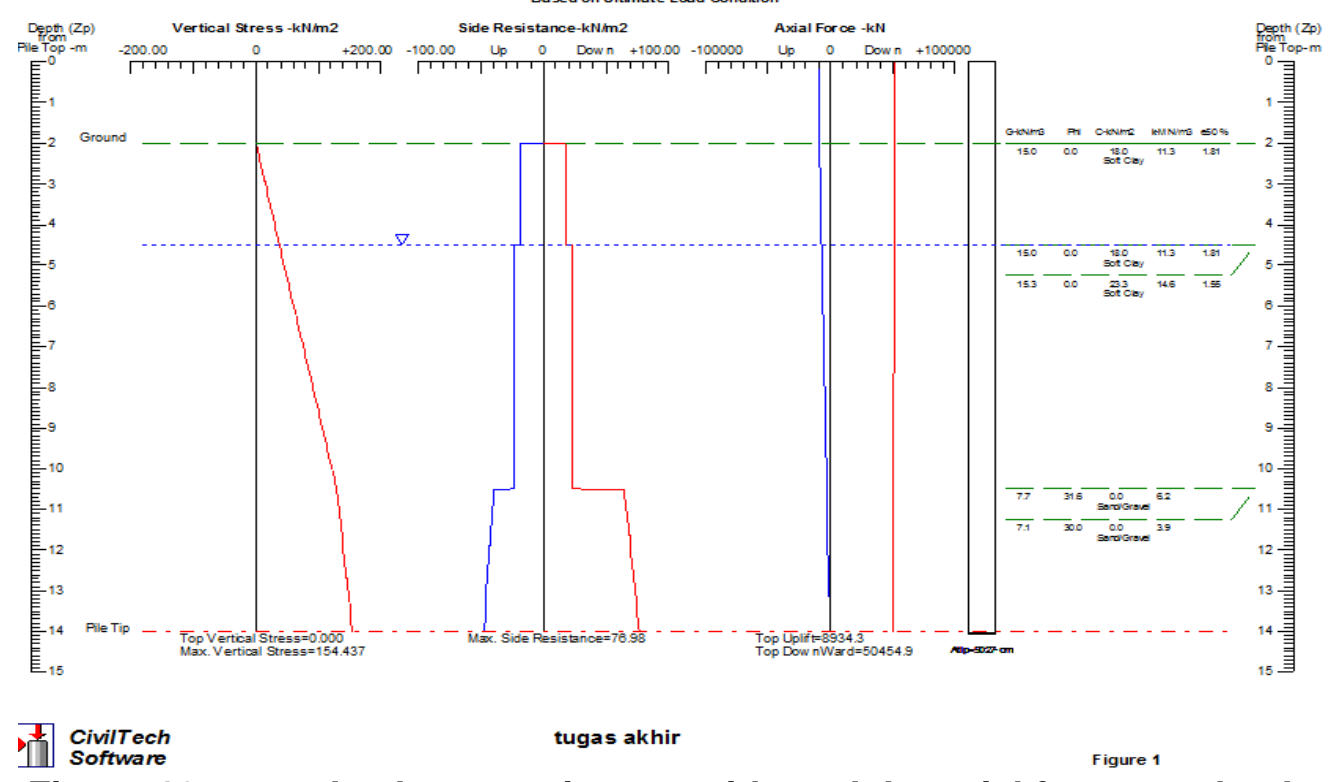

Figure 12 ground voltage, resistance side and the axial force vs. depth.

The resulting graph Settlement Expenses (Load settlement). 


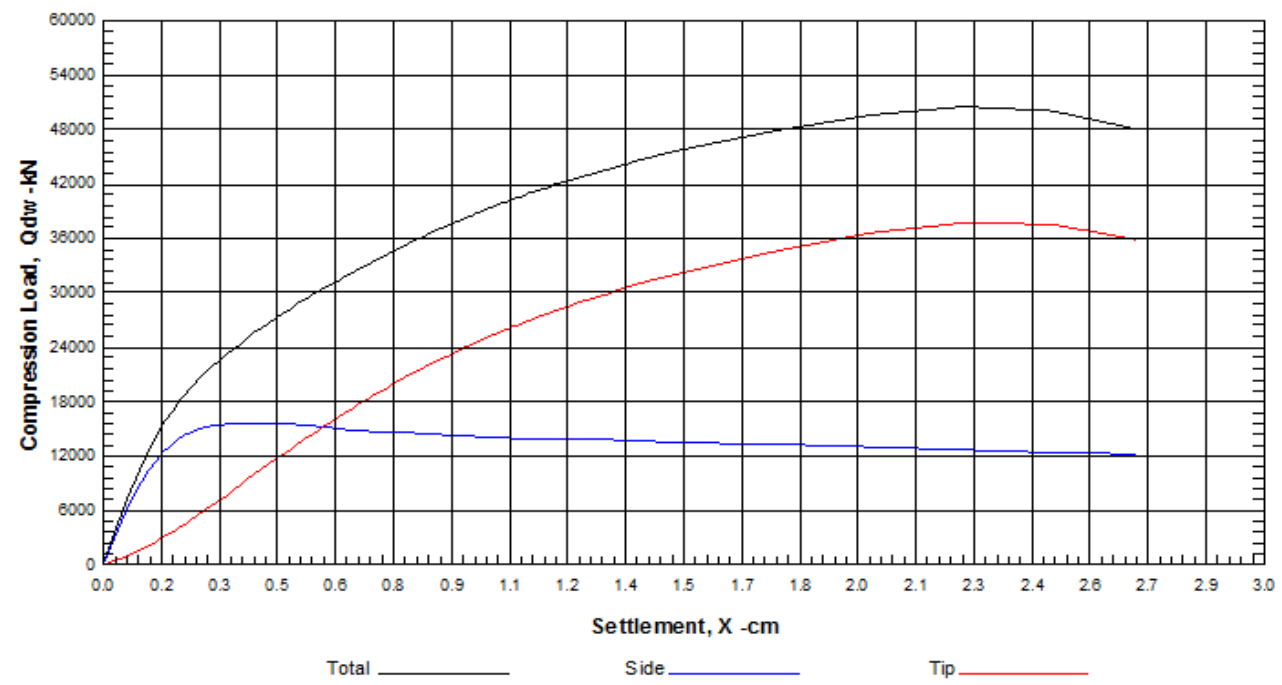

Figure 13. Load vs. vertical settlement.

Chart settlement proceeds Long Capacity (Capacity-Length).

ALLOWABLE CAPACITY vs FOUNDATION DEPTH
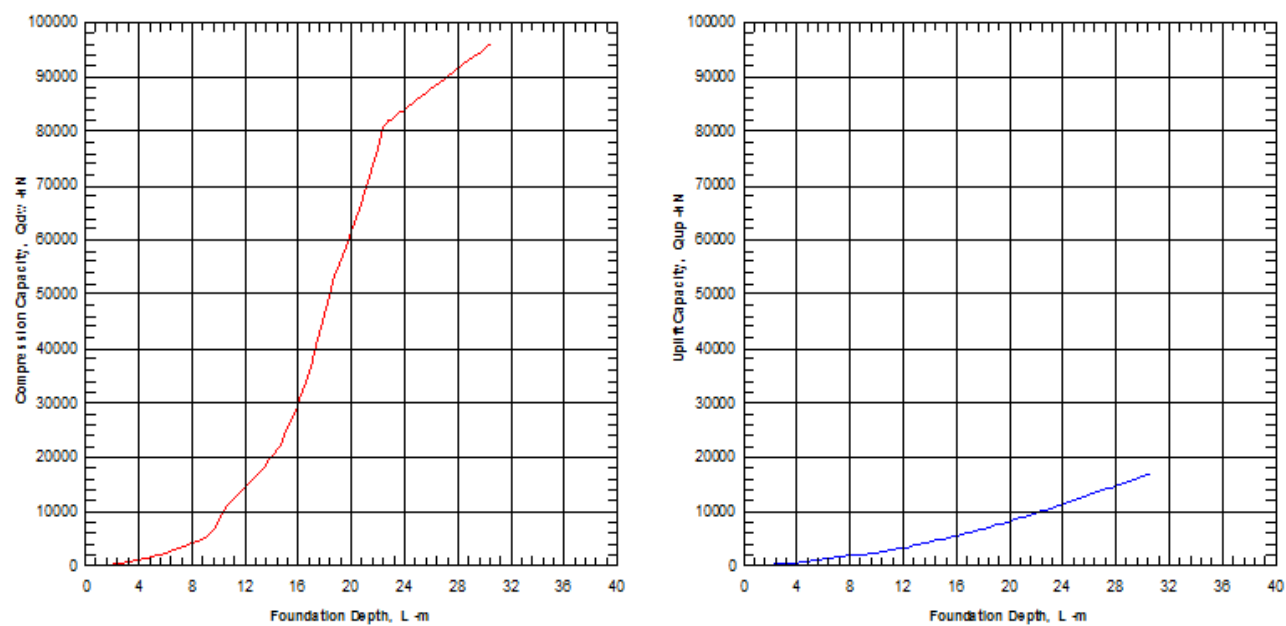

Figure 14 capacity allowed on the depth of the foundation.

The final result in the form of a summary of the data and results obtained from the application. 


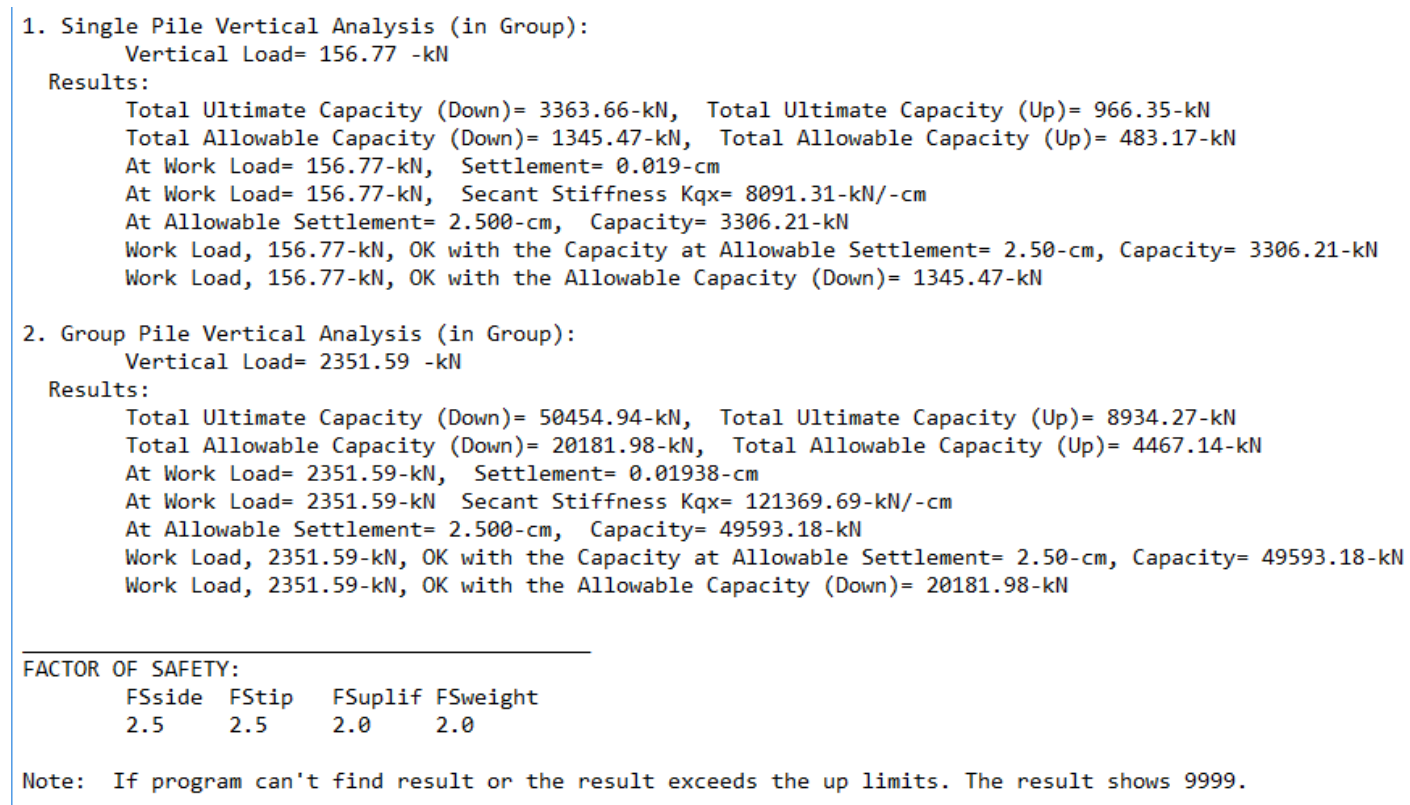

Figure 16 Summary results of the analysis of the load (Summary report).

a) Single Column Vertical Analysis Results (Group):

Vertical load given $=156.77-\mathrm{kN}$

Results:

Total Ultimate Capacity (Down) $=3363.66-\mathrm{kN}$

Total Ultimate Capacity $(\mathrm{SMA})=966.35-\mathrm{kN}$

Total capacity is Permitted (Down) $=1345.47-\mathrm{kN}$

The total capacity of the Center $($ Top $)=483.17-\mathrm{kN}$

When Workload $=156.77-\mathrm{kN}$

Settlement $=0.019-\mathrm{cm}$

On Workload $=156.77-\mathrm{kN}$

Secant stiffness-Kqx $=8091.31 \mathrm{kN} /-\mathrm{cm}$

At the completion $=2.500-\mathrm{cm}$

Capacity $=3306.21-\mathrm{kN}$

Workload, 156.77-kN

OK with capacity in Permitted Settlement $=2.50-\mathrm{cm}$, Capacity $=3306.21-\mathrm{kN}$

Workload, 156.77-kN,

OK with capacity Center (Down) $=1345.47-\mathrm{kN}$ (secure)

So on this analysis to get the expected results.

b. Pole Vertical Analysis Group (the Group):

Vertical load given $=2351.59-\mathrm{kN}$

Results:

Total Ultimate Capacity (Down) $=50454.94-\mathrm{kN}$

Total Ultimate Capacity $(S M A)=8934.27-\mathrm{kN}$

Total capacity is Permitted (Down) $=20181.98-\mathrm{kN}$

The total capacity of the Center $(\mathrm{Top})=4467.14-\mathrm{kN}$

On Workload $=2351.59-\mathrm{kN}$

Settlement $=0.01938-\mathrm{cm}$

Workplace-kN Load $=2351.59$

Secant stiffness Kqx Kqx = 121369.69-kN / -cm

In Settlement Settlement $=2.500-\mathrm{cm}$, Capacity $=49593.18-\mathrm{kN}$

Workload, 2351.59-kN

OK with capacity in Permitted Settlement $=2.50-\mathrm{cm}$

Capacity $=49593.18-\mathrm{kN}$

Workload, 2351.59-kN, 
OK with capacity Center (Down) $=20181.98-\mathrm{kN}$ (Aman)

So on this analysis to get the expected results.

\section{Lateral Load Calculation Results From Application ALLPILE V6.5e}

The initial view of the lateral calculation analysis.

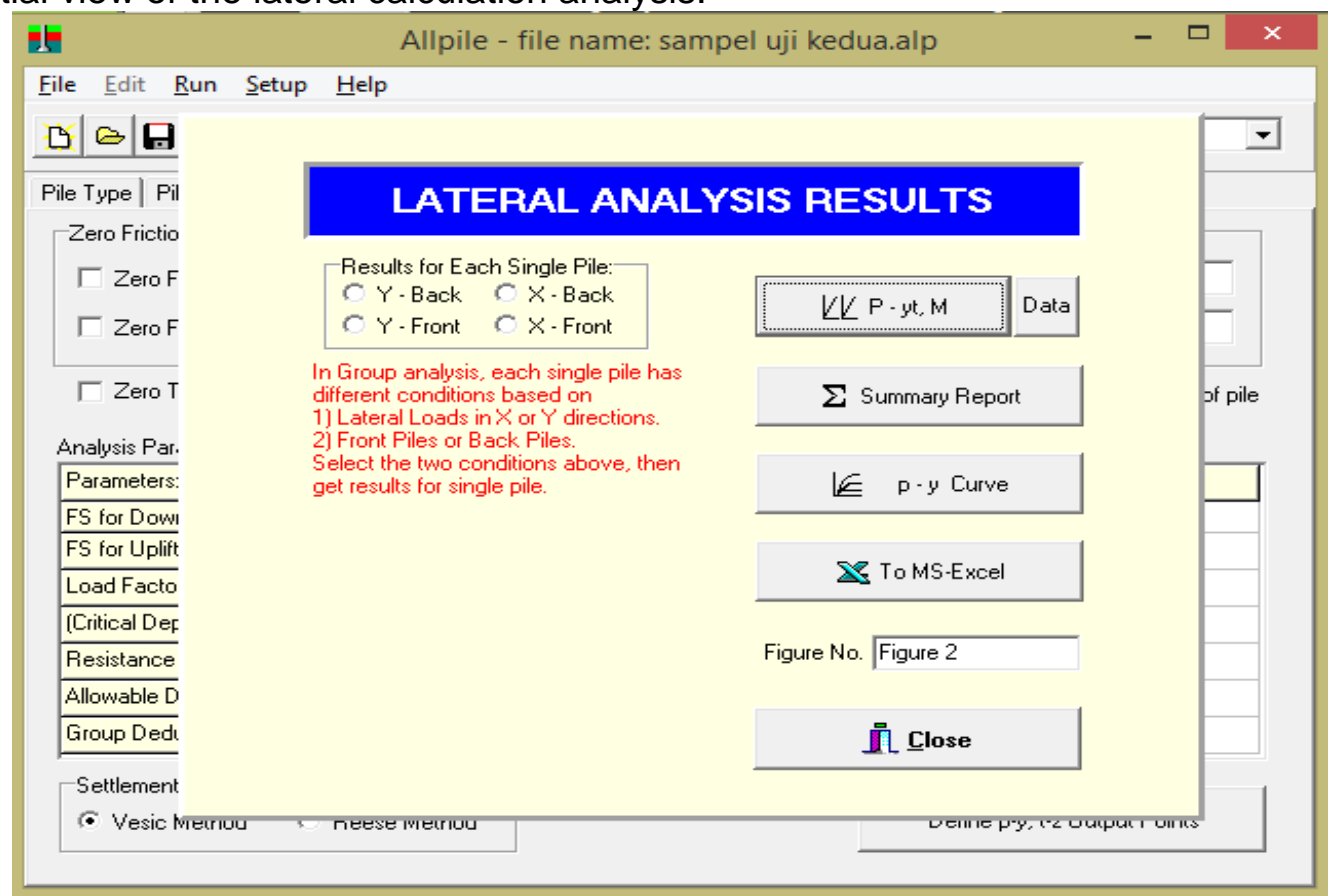

Figure 16 The initial view lateral analysis.

Graph lateral calculation results. Which displays the results of the calculations contained in the graph.

X-Directon, Group Plles

\section{LATERAL LOAD vs DEFLECTION \& MAX. MOMENT}
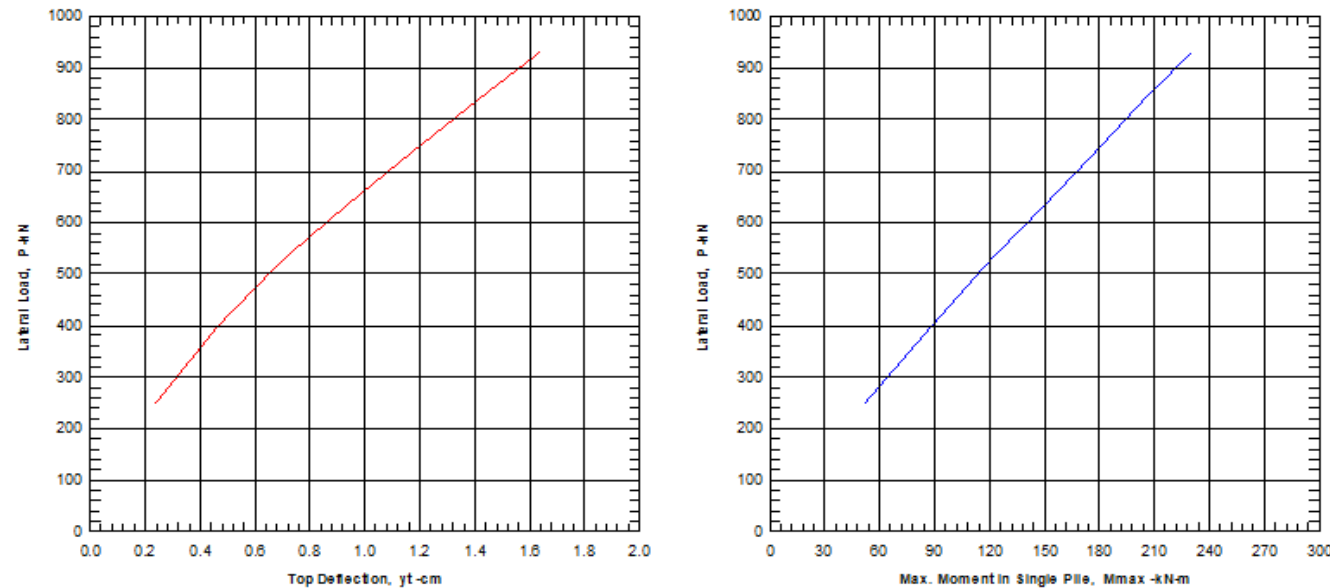

Figure 17 Graph lateral

The final result in the form of a summary of the data and results obtained from the application. 


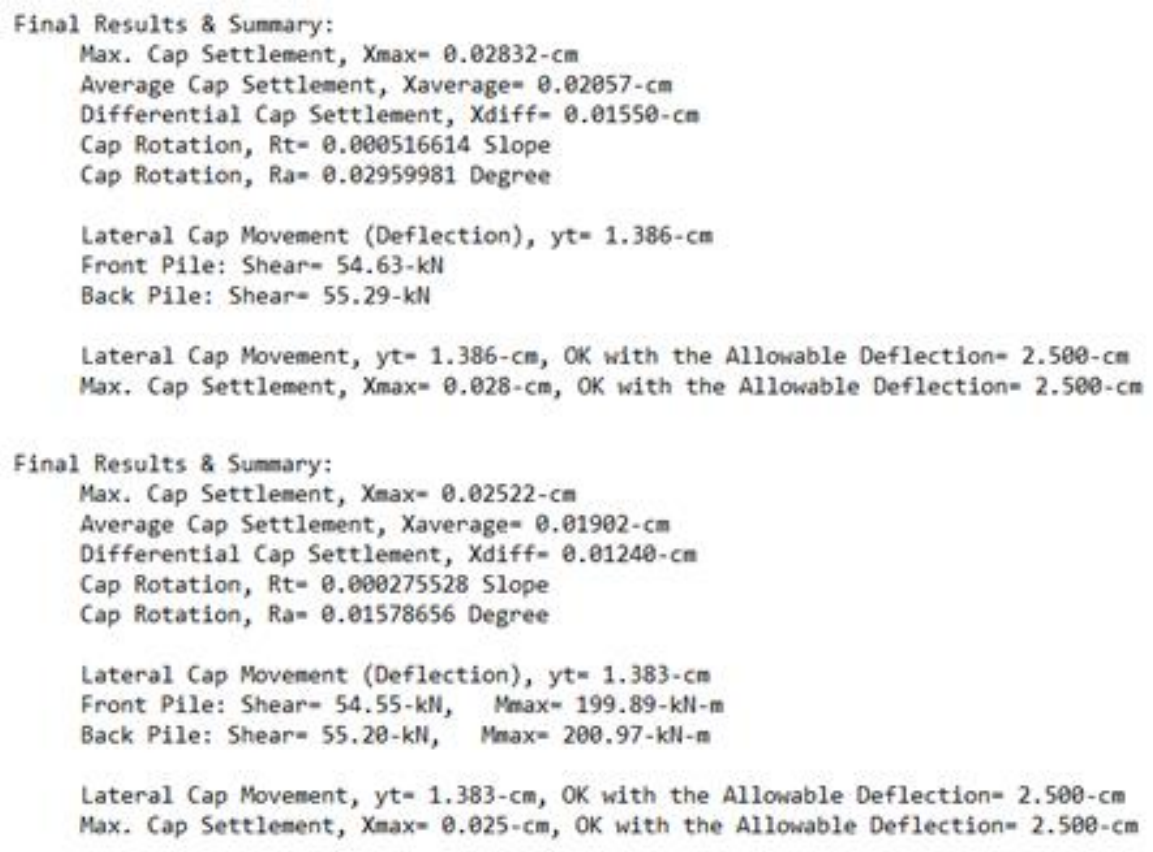

Figure 18 Summary results of the analysis of the load (Summary report).

a. Analysis Lateral Pole direction Y:

Summary \& Results:

Max. Cap Settlement, Xmax $=0.02832-\mathrm{cm}$

Settlement Cap Average, $X$ average $=0.02057-\mathrm{cm}$

Settlement, Xdiff $=0.01550-\mathrm{cm}$

Rotation on the pile cap, $\mathrm{Rt}=0.000516614$ Slope

Rotation on the pile cap, $\mathrm{Ra}=0.02959981$ Degrees

Close Lateral Movement (Deflection), yt $=1.386-\mathrm{cm}$

Stacks Home: Shear $=54.63-\mathrm{kN}$

Rows belakan: Shear $=55.29-\mathrm{kN}$

Close Lateral movement, yt $=1.386-\mathrm{cm}$,

OK with a deflection Permitted $=2.500-\mathrm{cm}$

Max. Completion of the pile cap, $\mathrm{Xmax}=0.028-\mathrm{cm}$,

OK with a deflection Permitted $=2.500-\mathrm{cm}$.

b. Analysis Lateral Pole direction X:

Summary \& Results:

Max. Cap Settlement, $X \max =0.02522-\mathrm{cm}$

Settlement Cap Average, $X$ average $=0.01902-\mathrm{cm}$

Cap Differential settlement, Xdiff $=0.01240-\mathrm{cm}$

Rotation on the pile cap, $\mathrm{Rt}=0.000275528$ Slope

Rotation on the pile cap, $\mathrm{Ra}=0.01578656$ Degrees

Close Lateral Movement (Deflection), yt $=1.383-\mathrm{cm}$

Stacks Front: Slide $=54.55-\mathrm{kN}, \mathrm{Mmax}=199.89-\mathrm{kN}-\mathrm{m}$

Back Pile: Shear $=55.20-k N$, Mmax $=200.97-k N-m$

Close Lateral movement, yt $=1.383-\mathrm{cm}$,

OK with a deflection Permitted $=2.500-\mathrm{cm}$

Max. Completion of the pile cap, $X \max =0.025-\mathrm{cm}$,

OK with a deflection Permitted $=2.500-\mathrm{cm}$

\section{CONCLUSIONS}

From the calculation of structural strength analysis of pile slab highway bridge

Randu village Merak - Probolinggo in stage 2 results are as follows: 
1. Strength and bearing capacity of pile on slab pile structure can be summarized as follows:

a. The maximum vertical force that occurs at the stake of 330.621 tons is still smaller than the carrying capacity of pile vertical license 185.3 tons, the pile is safe and able to bear the axial forces that occur.

b. Lateral forces that occur at the stake in the slab pile structure caused by environmental action force which acts style horizontal direction. The magnitude of the resultant force direction horizontal load to be borne by the stake was 23.07 tons. This value is still well below the carrying capacity of the laterally permission 54.55 tons, the pile is safe and able to bear the lateral forces that occur.

2. Test methods ALLPILE V6.5e modeling application can be used to predict the amount of ultimate capacity of pile groups of varying the amount of poles with pole $6 \mathrm{~cm}$ diameter, $24 \mathrm{~m}$ long and $1.5 \mathrm{~m}$ distance between the pole where $\mathrm{y}(\mathrm{kN})$ is the ultimate capacity and $x$ is number of poles, which is in accordance with a predetermined efficiency.

\section{Suggestion}

Based on this research is still far from kesempunaan and still found some deficiencies that need to be revised and some of the findings still need to be followed. For that put forward suggestions for other studies in the future:

1. Research development by changing the type of soil media are also strongly encouraged to be aware of the changes experienced by the carrying capacity of the pile when the soil media replaced.

2. Need development of the finite element method of analysis that has been done, such as a more detailed modeling of the pile foundation models that have been made, so that the results obtained are closer to modeling test results or the results of the analytical method.

3. Adding a pole length variation in order to know the changes experienced by the carrying capacity of the pile, and can determine the ratio $L / D$.

\section{REFERENCE}

[1]. Hardiyatmo, HC, 1996, the Foundation Engineering 1, PT. Gramedia Pustaka Utama, Jakarta.

[2]. Hardiyatmo, HC 2002, the Foundation Engineering 2, PT. Second Edition, Beta Offset, Yogyakarta.

[3]. Sardjono, HS, 1998, The foundation piles, volume 1, publisher Sinar Jaya Wijaya, Surabaya.

[4]. Sardjono, HS, 1998, The foundation piles, vol 2, publisher Sinar Jaya Wijaya, Surabaya.

[5]. Sulastri Sitohang 2009, Capability Analysis Foundation Piles On Building Project DJP And I Sumbagut KPP Jalan Suka Mulia Medan, Faculty of Engineering, Department of Civil Engineering, University of North Sumatra, Medan.

[6]. Braja M. Das, 2016, Principle Of Foundation Engineering, Eight Edition, Publisher Cengage Learning, USA.

[7]. Cheng Liu \& Jack B. Evett 2008, Soil And Foundation, The University of North Carolina at Charlotte, New Jersey.

[8]. Hilman Bramantio Hardana, 2018, Evaluation of Structural Strength Slab Bridge Pile mode At Toll jaln Segment Segment 3 Balikpapan-Samarinda STA $9+300$, Polytechnic Negri Samarinda, Samarinda.

[9]. Bowles, JE (1997). Analysis and Design Foundation, the fourth edition volume 1. Jakarta: Erland 